\title{
Penerapan Media Animasi Berbantukan Model Pembelajaran Inkuiri Terhadap Keterampilan Berpikir Kritis Siswa Pada Materi Struktur dan Fungsi Jaringan Tanaman
}

\author{
Norhalipah*, Ridha Nirmalasari \\ Tadris Biologi, Jurusan Pendidikan MIPA, FTIK, IAIN Palangka Raya, Kalimantan Tengah, \\ Indonesia.
}

*E-mail: norhalipah14@gmail.com

\begin{abstract}
Abstrak
Penelitian ini bertujuan untuk mendeskripsikan keterlaksanaan model inkuiri terbimbing berbantukan media animasi terhadap keterampilan berpikir kritis peserta didik dan mengetahui keterampilan berpikir kritis peserta didik melalui penerapan model inkuiri terbimbing berbantukan media animasi pada materi struktur dan fungsi jaringan tumbuhan kelas VIII MTS Islamiyah Palangka Raya. Penelitian ini menggunakan metode kuantitatif deskriptif desain penelitiannya menggunakan one group pretes postes. Instrumen yang digunakan adalah soal tes keterampilan berpikir kritis dengan 7 sub indikator dan lembar observasi keterlaksanaan pembelajaran. Teknik pengambilan sampel menggunakan porpusive sampling dengan jumlah peserta didik sebanyak 15 orang. Hasil penelitian menunjukan bahwa keterlaksanaan model pembelajaran inkuiri terbimbing berbantukan media animasi pada materi struktur dan fungsi jaringan tumbuhan kelas VIII A MTS Islamiyah Palangka Raya telah terlaksana dengan baik dengan persentase sebesar $84,09 \%$. Keterampilan berpikir kritis peserta didik termasuk dalam kriteria baik dilihat dari analisis pencapaian sub indikator keterampilan berpikir kritis.

Kata Kunci: Inkuiri Terbimbing, Keterampilan Berpikir Kritis, Struktur dan Fungsi Jaringan Tumbuhan
\end{abstract}

\begin{abstract}
This study aims to describe the implementation of the guided inkuiri model assisted by animation media to students 'critical thinking skills and to find out students' critical thinking skills through the application of the guided inkuiri model assisted by animation media on the structure and function material of plant networks class VIII MTS Islamiyah Palangka Raya. This research uses descriptive quantitative method, the research design uses one group pretest posttest. The instrument used was a question of critical thinking skills with 7 indicator aspects and an observation sheet of applied learning. The sampling technique used purposive sampling with a total of 15 students. The results showed the implementation of the guided inkuiri learning model assisted by animation media on the structure and function of plant tissue in class VIII A MTS Islamiyah Palangka Raya has been carried out well with a percentage of 84.09. Critical thinking skills of students are included in the good criteria seen from the analysis of the achievement of critical thinking indicators.
\end{abstract}

Keywords: Guided Inkuiri, Critical Thinking Skills, Structure and Function of Plant Tissue

\section{PENDAHULUAN}

Pandemi COVID-19 merupakan musibah yang memilukan di seluruh negara di dunia. Tanpa terkecuali di Indonesia, seluruh segmen kehidupan di Indonesia terganggu. Hal tersebut nampak jelas terlihat pada terhambatnya kegiatan pembelajaran yang mana biasanya berlangsung secara tatap muka hingga kini berubah menjadi pembelajaran daring. Hadirnya wabah COVID-19 yang sangat mengganggu, maka dari itu pendidikan di Indonesia mengalami perubahan dalam sistem pembelajaranya. Pendidik dituntut untuk membuat sistem pembelajaran yang dapat berjalan dengan baik meskipun dalam wabah COVID-19. Dalam memilih langkah pembelajaran daring yang baik pendidik harus seselektif mungkin, pendidik bukan membebani peserta didik dengan tugas-tugas yang diberikan untuk belajar di rumah tetapi pendidik juga hadir sebagai penggagas dan sebagai pentransfer ilmu dengan tetap 
mengutamakan ing ngarso sung tulada, ing madya mangun karsa, tut wuri handayani (Aji, 2020). Dengan kata lain, guru harus mampu mengemban tugas mengajar dan memastikan bahwa indikator yang dirancang dalam rencana pelaksanaan pembelajaran harus tercapai dengan nilai standar hingga melebihinya.

Tantangan pendidikan yang harus dihadapi kehidupan abad 21 adalah peserta didik dituntut untuk menguasai berbagai keterampilan. (Susilowati, dkk., 2017). Secara umum, keterampilan-keterampilan penting di abad 21 masih relevan dengan empat pilar kehidupan yang mencakup learning to know, learning to do, learning to be dan learning to live together keterampilan berpikir kritis terdapat didalam prinsip learning to do dan menjadi kemampuan pokok pada pembelajaran abad 21 dan itu berarti dalam dunia pendidikan, keterampilan berpikir kritis sudah merupakan kebutuhan bagi peserta didik, sehingga guru harus dapat mengembangkan keterampilan berpikir kritis pada peserta didik (Zubaidah, 2017).

Keterampilan berpikir kritis adalah potensi intelektual yang dapat dikembangkan melalui proses pembelajaran, dalam proses pembelajaran hendaknya guru melatih keterampilan berpikir kritis peserta didik untuk memberikan kesempatan peserta didik mengasah keterampilan berpikir kritis mereka (Susilowati, dkk., 2017). Keterampilan berpikir kritis mencakup kemampuan mengakses, menganalisis, mensintesis informasi yang dapat diajarkan, dilatih dan dikuasi. Selain keterampilan tersebut, keterampilan berpikir kritis juga menggambarkan keterampilan lainnya seperti keterampilan komunikasi dan informasi, keterampilan untuk memeriksa menganalisis, menafsirkan dan mengevaluasi (Wulandari, Penagaruh Model Discovery Learning Terhadapa Kemampuan berpikir kritis siswa pada konsep sistem ekskresi dI MAN 13 Jakarta, 2019). Oleh karena itu, keterampilan berpikir kritis diperlukan untuk mempersiapkan dirinya menghadapi kemajuan ilmu pengetahuan dan teknologi di adad ke 21, dimana informasi sangat melimpah dari berbagai sumber dan belum diketahui kebenarannya bahwa informasi tersebut benarbenar valid dan dapat dipertanggung jawabkan (Lestari, 2019).

Keterampilan berpikir kritis siswa setelah menggunakan model pembelajaran discovery learning (Wulandari, Penagaruh Model Discovery Learning Terhadapa Kemampuan berpikir kritis siswa pada konsep sistem ekskresi dI MAN 13 Jakarta, 2019) memiliki perbedaan dengan $\mathrm{N}$-Gain yang diperoleh sebesar $71,1 \%$ dalam kategori tinggi (A, Warda; E, Sudibyo., 2018). Berpikir kritis sangat dibutuhkan untuk mengantisipasi kemajuan ilmu pengetahuan dan teknologi, perlu dilakukan berbagai pembaharuan dan berbaikan dalam dunia pendidikan agar tercapainya keberhasilan dalam proses pembelajaran (Maryam, dkk., 2019). Keterampilan berpikir kritis peserta didik di jenjang pendidikan dapat diupayakan melalui proses pembelajaran yang memposisikan 
peserta didik terlibat dalam pembelajaran sebagai upaya melatih peserta didik menyelesaikan permasalahan yang dihadapi, oleh karena itu tahapan-tahapan model pembelajaran inkuiri terbimbing dapat mengakomodasi kegiatan-kegiatan yang mengarah pada keterampilan berpikir kritis peserta didik. Model pembelajaran inkuiri terbimbing merupakan alternatif dalam pembelajaran IPA untuk dapat menumbuhkan keterampilan berpikir kritis peserta didik di sekolah.

Model pembelajaran inkuiri terbimbing merupakaan model pembelajaran yang mendorong peserta didik untuk mengoptimalkan kemampuannya (Yeritia, S; Rahayu, S; Wahyudi., 2017). Model pembelajaran inkuiri juga dapat dikombinasikan dengan berbagai media pembelajaran. Salah satunya dengan LKS yang mana ada satu penelitian yang menunjukkan bahwa LKS berbasis inkuiri terbimbing layak dan efektif dalam materi struktur dan fungsi jaringan tumbuhan (D, Selviana; R, Susanti; RS, Iswari., 2016). Inkuiri terbimbing suatu model pembelajaran yang melibatkan seluruh kemampuan peserta didik untuk mencari dan menyelidiki suatu permasalahan secara kritis, logis, dan analitis untuk mencari dan menemukan sendiri jawaban dari suatu permasalahan yang dipertanyakan dengan bimbingan guru dengan penuh percaya. Melalui kegiatan tersebut, peserta didik dapat belajar untuk penyajian masalah, membuat hipotesis, melakukan percobaan untuk memperoleh informasi, mengumpulkan dan menganalisis data, dan membuat simpulan.
Model pembelajaran ini guru bertindak sebagai organisator dan fasilitator. Guru tidak memberitahukan konsep-konsep tetapi membimbing peserta didik menemukan konsep-konsep tersebut melalui kegiatan belajar, sehingga konsep yang didapat berdasarkan kegiatan dan pengalaman belajar tersebut akan selalu dingat peserta didik dalam waktu yang lama. Untuk melakukan suatu pembelajaran juga diperlukan media pembelajaran untuk memudahkan guru dalam menjelaskan kepada peserta didik agar mendapatkan pengetahuan dan membantu peserta didik memahami pengetahuan, maka guru perlu menggunakan media pembelajaran terutama dengan memanfaatkan keberadaan ilmu pengetahuan dan teknologi.

Berdasarkan latar belakang, untuk mendeskripsikan keterlaksanaan model inkuiri terbimbing berbantukan media animasi terhadap keterampilan berpikir kritis peserta didik dan mengetahui keterampilan berpikir kritis peserta didik melalui penerapan model inkuiri terbimbing berbantukan media animasi pada materi struktur dan fungsi jaringan tumbuhan kelas VIII MTS Islamiyah Palangka Raya

\section{METODE PENELITIAN}

Penelitian ini merupakan penelitian pra eksperimen. Desain penelitian digunakan, yaitu One-Group Pretest-Posttest Design. Populasi penelitian ini adalah peserta didik kelas VIII A MTS Islamiyah Palangka Raya Tahun ajaran 2020/2021. Pemilihan sampel dalam penelitian ini dilakukan dengan teknik purposive sampling, yaitu pengambilan 
anggota sampel dari populasi dilakukan berdasarkan pertimbangan tertentu dengan pertimbangan bahwa peserta didik pada kelas tersebut memiliki kemampuan mudah untuk dikontrol dan jumlah paling banyak peserta didik yang mempunyai media untuk mendukung pembelajaran daring. Sampel pada penelitian ini adalah kelas VIII A yang berjumlah 15 peserta didik.

Penelitian ini dilaksanakan pada bulan September, semester ganjil Tahun ajaran 2020/2021 yang bertempat di MTS Islamiyah Palangka Raya. Penelitian dilakukan sebanyak 7 kali pertemuan dimana 4 kali pertemuan digunakan untuk proses pembelajaran sedangkan 2 kali pertemuan untuk tes keterampilan berpikir kritis peserta didik. Selama proses pembelajaran diterapkan model pembelajaran inkuiri terbimbing berbantukan media animasi.

Instrumen yang digunakan, yaitu tes dan non-test. Tes digunakan untuk mengumpulkan data guna melihat keterampilan berpikir kritis yang disusun berdasarkan sub indikator keterampilan berpikir kritis. Adapun sub indikator keterampilan berpikir kritis yang meliputi: memfokuskan pertanyaan, menganalisis argumen, bertanya dan menjawab pertanyaan klarifikasi dan pertanyaan menantang, mempertimbangkan kredibilitas suatu sumber dengan kriteria, membuat dedukasi dan mempertimbangkan hasil dedukasi, mendefinisikan istilah dan mempertimbangkan definisi (RN, Sunardjo; SA, Yudhianto; T. Rahman, 2016). Kemudian, diadaptasi menjadi 7 sub indikator yang integrasikan ke dalam Soal pilihan ganda berjumlah 35 soal. Namun, sebelum digunakan dilakukan validasi terlebih dahulu, yaitu validasi oleh ahli. Sebelum soal tes digunakan maka diadakan uji coba pada instrumen tersebut untuk mengukur keabsahan instrumen dengan menggunakan uji validitas dan uji reliabilitas, dan untuk mengetahui kualitas instrumen, yaitu dengan menguji daya beda soal dan tingkat kesukaran soal. Selain itu, lembar observasi juga digunakan untuk mengetahui proses pembelajaran yang disusun berdasarkan tahapan model pembelajaran inkuiri terbimbing berbantukan media animasi.

Data hasil lembar observasi keterlakasanaan model pembelajaran dianalisis dengan langkah tabulasi data skor hasil observasi dengan menggunakan skala Guttman, yaitu dengan skor 1 untuk "Ya" dan skor 0 untuk "Tidak". Kemudian, untuk menghitung rata-rata skor tiap aspek yang didapat dari dua orang pengamat untuk selanjutnya dijumlahkan serta dihitung persentase.

Analisis keterampilan berpikir kritis untuk menghitung $\mathrm{N}$-gain guna untuk mengetahui peningkatan pemahaman peserta didik setelah pembelajaran berlangsung. Gain adalah selisih antara nilai pretes dan postes peserta didik. Adapun interpretasi N-Gain berikut (RR, 1999) yang akan diadaptasi.

Table 1. Interpretasi Indeks N-Gain

\begin{tabular}{cc}
\hline Indeks $\mathbf{N}-$ Gain & Interpretasi \\
\hline $\mathrm{N}$-Gain $\geq 0,7$ & Tinggi \\
$0,3 \leq \mathrm{N}-$ Gain $\leq 0,7$ & Sedang \\
$\mathrm{N}-$ Gain $<0,3$ & Rendah \\
\hline
\end{tabular}


Analisis Pencapaian Sub indikator berpikir kritis di analisis dengan langkah (1) Menghitung nilai soal benar perindikator, (2) Menghitung nilai persoal dengan rumus :

$K B K=\frac{\text { Jumlah menjawab benar }}{\text { jumlah peserta didik }} \times 100$

Menghitung rata-rata per indikator dengan rumus :

$K B K=\frac{\text { Jumlah nilai persoal }}{\text { jumlah soal per indikator }} \times 100$

Hasil analisis sub indikator keterampilan berpikir kritis yang diperoleh peserta didik selama proses pembelajaran di kategorikan sebagai berikut :

Table 2. Klasifikasi Rentang Nilai Terhadap Keterampilan Berpikir Kritis (KBK).

\begin{tabular}{cc}
\hline $\begin{array}{c}\text { Rentang Nilai } \\
(\boldsymbol{\%})\end{array}$ & Kategori \\
\hline $0,00-20,00$ & Sangat kurang \\
$20,00-39,99$ & Kurang \\
$40,00-59,99$ & Cukup \\
$60,00-79,99$ & Baik \\
$80,00-99,99$ & Sangat Baik \\
\hline
\end{tabular}

Sumber : (Arikunto, 2006)

Analisis deskriptif adalah penggunaan metode deskriptif bertujuan untuk mengumpulkan informasi mengenai status pada gejala yang ada, yaitu menurut apa adanya pada saat penelitian dilakukan (Arikunto, 2006). Sebagaimana dikemukakan oleh Sudjana bahwa metode penelitian deskriptif dengan pendekatan kuantitatif digunakan apabila bertujuan untuk menjelaskan peristiwa atau suatu kejadian yang terjadi pada saat sekarang dalam bentuk angka-angka yang bermakna (Siswandi, 2011).

\section{HASIL DAN PEMBAHASAN}

Penilaian keterlaksanaan guru dalam mengelola kegiatan pembelajaran dengan menggunakan model pembelajaran inkuiri terbimbing pada materi struktur dan fungsi jaringan tumbuhan, dinilai dengan menggunakan lembar observasi. Lembar pengamatan yang digunakan telah dikonsultasikan dan divalidasi oleh dosen ahli sebelum dipakai untuk mengambil data penelitian. Pengamatan pada keterlaksanaan model ini dilakukan oleh 2 orang pengamat pada saat pembelajaran diberikan.

Table 3. Rata-rata Presentase per Pertemuan

\begin{tabular}{ccc}
\hline Pertemuan & Nilai & Kategori \\
\hline I & 72,73 & Cukup \\
II & 81,82 & Baik \\
III & 86,36 & Baik \\
IV & 95,45 & Sangat Baik \\
\hline Rata - Rata & \multicolumn{2}{c}{$84,09 \%$} \\
\hline
\end{tabular}

Penilaian keterlaksanaan model ini meliputi beberapa aspek yang telah diuraikan pada lembar pengamatan. Data yang tersaji merupakan data yang telah dirata-ratakan dari hasil yang telah diberikan oleh 2 pengamat atau observer. Adapun data ini merupakan data dari lembar observasi yang menggunakan Skala Guttman yaitu 1 untuk "ya" dan 0 untuk "tidak", data rata-rata tersebut ditampilkan dalam bentuk persentase (\%) disajikan pada Tabel 3.

Berdasarkan Tabel 3, terlihat bahwa data hasil penilaian keterlaksanaan model pembelajaran inkuiri terbimbing berbantukan media animasi pada setiap pertemuan mengalami peningkatan. Penilaian keterlaksanaan model pembelajaran ini oleh guru secara keseluruhan didapat rata-rata penilaian sebesar 84,09\% dengan kategori baik. Apabila dibandingkan dengan penelitian sebelumnya (A, Warda; E, Sudibyo., 2018), 
persentase $84,09 \%$ tersebut lebih besar daripada $71,1 \%$ walaupun berbeda materi dan model pembelajaran yang diberikan. Keterlaksanaan model pembelajaran inkuiri terbimbing berbantukan media animasi pada penelitian ini ada beberapa kegiatan model inkuiri terbimbing berbantukan media animasi yang tidak terlaksana secara maksimal, hal ini dikarenakan terdapat kendala dalam pelaksanaannya. Kendala tersebut yaitu kurangnya peserta didik dalam mengelolaan waktu dalam proses pembelajaran.

\section{a. Deskripsi Pre-test, Post-test, Gain dan}

\section{N-gain keterampilan Berpikir Kritis}

Data hasil penelitian menunjukkan bahwa keterampilan berpikir peserta didik mengalami peningkatan disetiap proses pembelajaran hal ini, hal berdasarankan ini berdasarkan LKPD yang diberikan pada peserta didik saat berlangsungnya pembelajaran pada saat diskusi. Keteramplilan berpikir kritis peserta didik dari data skor Pretest dan Post-test yang diperoleh dari kelas eksperimen berdasarkan nilai ketuntasan individual yang diterapkan oleh sekolah. Hasil menunjukan bahwa ada peningkatan nilai dari Pre-test ke Post-test. Selanjutnya nilai yang diperoleh tersebut di analisis untuk di cari ratarata hasil belajar, gain, N-gain. Data yang didapatkan kemudian akan dianalisis secara deskriptif. Nilai keterampilan berpikir kritis baik pretest maupun postest dibandingkan dengan menghitung $\mathrm{N}$-gain guna untuk mengetahui peningkatan pemahaman peserta didik setelah proses pembelajaran. Untuk mengatahui keterampilan berpikir kritis peserta didik setelah pembelajaran berlangsung dapat dilihat pada Tabel 4.

Table 4. Rata-rata Kemampuan Berpikir Kritis Kelas VIII A MTs Islamiyah Palangka Raya

\begin{tabular}{|c|c|c|c|c|c|c|}
\hline \multirow[b]{2}{*}{ No } & \multirow{2}{*}{$\begin{array}{l}\text { Kode } \\
\text { Siswa }\end{array}$} & \multicolumn{4}{|c|}{ Hasil } & \multirow[b]{2}{*}{ KRITERIA } \\
\hline & & $\begin{array}{l}\text { PRE- } \\
\text { TEST }\end{array}$ & $\begin{array}{c}\text { POST- } \\
\text { TEST }\end{array}$ & Gain & $\begin{array}{c}\mathrm{N}- \\
\text { gain }\end{array}$ & \\
\hline 1 & S01 & 57 & 80 & 23 & 0,53 & Sedang \\
\hline 2 & S02 & 69 & 94 & 25 & 0,81 & Tinggi \\
\hline 3 & S03 & 54 & 71 & 17 & 0,37 & Sedang \\
\hline 4 & S04 & 34 & 71 & 37 & 0,56 & Sedang \\
\hline 5 & S05 & 46 & 80 & 34 & 0,63 & Sedang \\
\hline 6 & S06 & 40 & 83 & 43 & 0,72 & Tinggi \\
\hline 7 & S07 & 51 & 71 & 20 & 0,41 & Sedang \\
\hline 8 & S08 & 34 & 66 & 32 & 0,48 & Sedang \\
\hline 9 & S09 & 54 & 74 & 20 & 0,43 & Sedang \\
\hline 10 & S10 & 60 & 77 & 17 & 0,43 & Sedang \\
\hline 11 & S11 & 40 & 74 & 34 & 0,57 & Sedang \\
\hline 12 & S12 & 31 & 69 & 38 & 0,55 & Sedang \\
\hline 13 & S13 & 40 & 63 & 23 & 0,38 & Sedang \\
\hline 14 & S14 & 51 & 77 & 26 & 0,53 & Sedang \\
\hline 15 & S15 & 31 & 71 & 40 & 0,58 & Sedang \\
\hline \multicolumn{2}{|c|}{ Rata - Rata } & 46 & 75 & 29 & $\mathbf{0 , 5 3}$ & \\
\hline
\end{tabular}


Tabel 4 menunjukan bahwa nilai rata-rata Pretest hasil belajar peserta didik sebelum dilaksanakan pembelajaran pada kelas eksperimen adalah 46. Kemudian terjadinya peningkatan rata-rata Post test dengan rata-rata 75. Nilai gain pada kelas eksperimen adalah sebesar 29 sedangkan nilai $N$-gain pada kelas eksperimen menunjukkan kategori sedang dengan nilai 0,53 .

\section{b. Analisis Pencapaian Sub Indikator Keterampilan Berpikir Kritis}

Table 5. Analisis Pencapain Sub Indikator Berpikir Kritis

\begin{tabular}{|c|c|c|c|}
\hline No & Sub Indikator & $\begin{array}{c}\text { Skor } \\
\text { rata-rata }\end{array}$ & Kategori \\
\hline 1 & $\begin{array}{l}\text { Mengidentifikasi dan } \\
\text { Merumuskan kriteria } \\
\text { untuk } \\
\text { mempertimbangkan } \\
\text { kemungkinan } \\
\text { jawaban. }\end{array}$ & 80,00 & $\begin{array}{l}\text { Sangat } \\
\text { Baik }\end{array}$ \\
\hline 2 & $\begin{array}{l}\text { Mengidentifikasi dan } \\
\text { merumuskan } \\
\text { pertanyaan }\end{array}$ & 64,00 & Baik \\
\hline 3 & $\begin{array}{l}\text { Mengidentifikasi } \\
\text { Kesimpulan }\end{array}$ & 70,67 & Baik \\
\hline 4 & $\begin{array}{l}\text { Memberikan } \\
\text { penjelasan }\end{array}$ & 78.67 & Baik \\
\hline 5 & Menyebutkan contoh & 68,00 & Baik \\
\hline 6 & $\begin{array}{l}\text { Mempertimbangkan } \\
\text { penggunaan prosedur } \\
\text { dengan tepat }\end{array}$ & 84,00 & $\begin{array}{l}\text { Sangat } \\
\text { Baik }\end{array}$ \\
\hline 7 & $\begin{array}{l}\text { Menarik kesimpulan } \\
\text { dari hasil } \\
\text { penyelidikan }\end{array}$ & 77,33 & Baik \\
\hline
\end{tabular}

Berdasarkan Tabel 4 analis pencapaian sub indikator berpikir kritis di atas dapat dijelaskan sebagai berikut.

1. Mengidentifikasi dan merumuskan kriteria untuk mempertimbangkan kemungkinan jawaban memiliki persentase 80, 00 dengan kategori sangat baik.
2. Mengidentifikasi dan merumuskan pertanyaan memiliki persentase 64,00 dengan kategori baik

3. Mengidentifikasi Kesimpulan memiliki persentase 70,67 dengan kategori baik

4. Memberikan penjelasan memiliki persentase 78.67 dengan kategori baik

5. Menyebutkan contoh persentase 68,00 dengan kategori baik.

6. Mempertimbangkan penggunaan prosedur dengan tepat memiliki persentase 84,00 dengan kategori sangat baik.

7. Menarik kesimpulan dari hasil penyelidikan memiliki memiliki persentase 77,33 dengan kategori baik.

Kemampuan peneliti dalam menerapkan model pembelajaran inkuiri terbimbing berbantukan media animasi yang dinilai oleh dua orang pengamat menggunakan lembar pengamatan pengelolaan pembelajaran secara daring yang telah dilakukan dalam 4 kali pertemuan dengan alokasi waktu $2 \times 40$ menit pada setiap kali pertemuan. Keterlaksanaan model pembelajaran inkuiri terbimbing berbantukan media animasi termasuk kategori baik. Hal ini ditunjukkan dengan adanya peningkatan pada setiap pertemuan. Adanya peningkatan-peningkatan ini menunjukkan bahwa peneliti telah mampu menerapkan model pembelajaran inkuiri terbimbing berbantukan media animasi dengan baik. Keterlaksanaan peneliti pada pembelajaran model ini dikatakan baik karena sesuai dengan pendapat (Trianto, 2012) bahwa tahapan pembelajaran inkuiri terbimbing akan mudah tercapai dengan bimbingan guru dan 
salah satu kelebihan model inkuiri yaitu memberikan ruang kepada peserta didik untuk belajar sesuai dengan gaya belajar mereka sehingga peserta didik mudah beradaptasi dengan model pembelajaran ini.

Dalam proses pembelajaran peneliti mengalami banyak kemudahan saat menggunakan Zoom. Aplikasi ini dilengkapi fitur Share Screen yang mampu memfasilitasi kebutuhan pengajar dalam menyajikan bahan ajar layaknya pertemuan tatap muka didalam kelas kepada peserta didik. Hasil penelitian ini sejalan (Cecilia, 2020) dengan artikelnya yang berjudul PjBL model pembelajaran bermakna dimasa pandemi Covid-19 karena peserta didik dapat mengembangkan kemampuan untuk memfokuskan diri. Hal ini diperkuat (Suryobroto, 2002 ) bahwa model pembelajaran inkuiri terbimbing dapat lebih membangkitkan gairah sehingga peserta didik dapat lebih aktif dan memberikan motivasi pada peserta didik misalkan peserta didik merasakan jerih payah penyelidikannya, menemukan keberhasilan dan kadang-kadang kegagalan. Selain itu, dengan adanya bimbingan ini dapat memperkuat pribadi peserta didik dengan bertambahnya kepercayaan pada diri sendiri melalui prosesproses penemuan.

Pelaksanaan model pembelajaran inkuiri terbimbing berbantukan media animasi dilakukan dengan memberikan masalah kepada peserta didik dalam bentuk lembar kerja peserta didik. Hal ini diperkuat oleh (Ridho, 2017) berdasarkan hasil penelitian dan pembahasan disimpulkan bahwa peserta didik yang dibelajarkan dengan media animasi memiliki hasil belajar yang lebih tinggi dibandingkan dengan peserta didik yang dibelajarkan dengan media gambar dengan alur pembelajaran disesuaikan dengan tahapan pembelajaran inquiri terbimbing

Kurang masksimalnya peserta didik dalam mengelola waktu sehingga ada beberapa langkah pembelajaran yang tidak terlaksana. Sedangkan, pengelolaan waktu dalam proses pembelajaran merupakan salah satu hal yang sangat penting, karena jika waktu tidak dimanfaatkan secara efisien dan efektif maka dapat berdampak terhadap pembelajaran yang tidak maksimal/tuntas. Hal ini sejalan dengan pendapat dari Ali (2008) dan Gunawan (2009) yang menyatakan bahwa salah satu hambatan yang sering dialami dalam mengajar adalah soal waktu. Apabila seorang peseta didik tidak dapat menggunakan waktu dengan disiplin (tidak efekti dan efisien) pada kegiatan pembelajaran sejak kegiatan awal, inti dan kegiatan akhir dapat berdampak pada bahan materi belum tersampaikan dengan tuntas dan tujuan pembelajaran tidak sepenuhnya tercapai.

Waktu merupakan sumber terbatas yang perlu dialokasi dan dimanfaatkan secara efisien dan efektif, guna mengoptimalkan pemanfaatan waktu yang tersedia untuk kebutuhan pembelajaran, guru perlu memperhatikan beberapa petunjuk yaitu seperti yang disampaikan oleh Munzali (2011) dalam Sabri (2012) yang menyebutkan beberapa hal yang perlu diperhatikan: (1) hindari waktu yang terbuang akibat keterlambatan penyiapan sumber atau media, penundaan memulai awal pembelajaran, (2) 
mulai pembelajaran pada waktunya, (3) hindari menghentikan PBM sebelum waktunya, (4) hindari terjadinya hal-hal yang dapat menganggu selama proses pembelajaran, (5) tingkatkan time on-task setiap peserta didik untuk mengikuti setiap sesi pembelajaran.

Berdasarkan interview singkat testimoni Peserta didik tentang pelaksanaan pembelajaran secara online, Peserta didik menganggap bahwa pembelajaran melalui Zoom Meeting sangat menguras kouta mereka. Latar belakang peserta didik dikelas VIII A yang peniliti ampu, memiliki kondisi ekonomi yang heterogen. Untuk itu, maka kendala yang terkait langsung dengan nilai ekonomi harus disiasati secara bijak, agar proses belajar secara daring dapat berlangsung secara adil. Menurut peneliti mengingat Zoom merupakan aplikasi live streaming yang memiliki karakter boros kuota, maka durasi live streaming yang dilakukan dapat dipersingkat agar interaksi antara pengajar dan pembelajar dapat tetap terjalin layaknya pembelajaran didalam kelas. Selanjutnya untuk mensiasati ketimpangan interaksi antara pengajar dan pembelajar penyampaian materi selanjutnya dan pengumpulan tugas dapat dilakukan melalui WhatsApp group yang dapat dipantau secara real time dan intens. Fungsi WhatsApp group tersebut adalah sebagai media pelengkap dari apa yang sudah peneliti sampaikan pada zoom. Dalam WhatsApp Gruop peneliti kerap mengirimkan penjelasan tambahan agar tujuan belajar dapat tercapai sesuai rencana pembelajaran yang sudah disusun sebelumnya.

Data hasil penelitian menunjukkan bahwa keterampilan berpikir peserta didik mengalami peningkatan disetiap proses pembelajaran hal ini, hal berdasarankan ini berdasarkan LKPD yang diberikan pada peserta didik saat berlangsungnya pembelajaran pada saat diskusi. Hal ini dapat diketahui dari hasil diskusi mulai dari merumuskan masalah, merumuskan hipotesis, mengumpulkan informasi, mengolah data dan menarik kesimpulan.

Pertemuan pertama dengan menggunakan model pembelajaran inkuiri terbimbing. Kemudian dengan menampilkan media animasi, kemudian peserta didik membuat rumusan masalah, hipotesis sementara dari masalah yang disajikan di LKPD, disaat ini peserta didik masih mengalami kendala terkait bagaimana membuat hipotesis itu, dan bertanya kepada guru yang mengajar mengenai cara pemecahan masalah tersebut. Selanjutnya setelah paham dengan penjelasan dari guru sebelumnya peserta didik mengumpulkan informasi dari buku catatan atau buku paket, diteruskan mengolah data dari buku catatan atau buku paket, dan menarik kesimpulan dari hasil masalah yang diberikan. Kemudian pada saat memaparkan hasil hipotesis dan tanya jawab peserta didik kurang antusias dan hanya sebagian kecil yang merasa antusias terkait pemahaparan kelompok yang maju kedepan.

Pada pertemuan kedua, ketiga dan ke empat peserta didik sudah mulai paham dengan bagaimana membuat rumusan masalah, membuat hipotesis, merancang percobaan, melakukan percobaan, mengumpulkn data, mengoah data dan menarik kesimpulan. Pada pertemuan kedua 
dan ketiga dan keempat ini peserta didik sudah mulai terbiasa dengan model pembelajaran inkuiri terbimbing untuk meningkatkan keterampilan berpikir kritis. Hal ini dapat terlihat dari hasil LKPD yang mereka kerjakan sudah mulai terperinci untuk membuat hipoteisis dan menemukan suatu masalah yang sudah disajikan. Jadi dapat disimpulkan bahwa model pembelajaran terbimbing memiliki pengaruh terhadap peningkatkan keterampilan berpikir kritis peserta didik pada saat diskusi hal ini terlihat dari hasil diskusi.

Dalam suatu Hadist Riwayat Al-Darimi (Al-Darimi), "Dari Abdurrahman bin Abi Laili berkata: Berdiskusilah kamu, sesungguhnya berkembangnya sebuah hadist muncul dari diskusi tersebut". Salah satu model yang digunakan dalam penerapan model pembelajaran inkuiri terbimbing ini adalah metode diskusi. Diskusi merupakan suatu proses yang teratur yang melibatkan sekelompok orang (Usman, 2006). Diskusi juga merupakan proses bertukaran pikiran ataupun pembahasan suatu masalah (Ali, 2006). Metode diskusi juga memiliki beberapa manfaat antara lain dapat memperdalam pengetauhuan yang telah dikuasai peserta didik dan dapat melatih peserta didik untuk mengidentifikasi dan memecahkan masalah serta mengambil kesimpulan jawaban dari pemecahan masalah tersebut (Suhandi, 2011). Diskusi juga sangat efektif diterapkan untuk mengatasi masalah kemamuan peserta didik dalam berkomunikasi (Siswandi, 2006).

Merujuk pada Kriteria pada Tabel 2 menunjukkan bahwa peningkatan keterampilan berpikir kritis peserta didik diukur sebelum proses pembelajaran menggunakan model pembelajaran inkuiri terbimbing berbantukan media animasi di kelas eksperimen memiliki rata-rata nilai pada kelas VIII A sebesar $46 \%$. Kemudian setelah proses pembelajaran menggunakan model inkuiri terbimbing berbantukan media animasi memiliki rata-rata nilai pada keterampilan berpikir kritis kelas VIII A sebesar sebesar $75 \%$. Berdasarkan hasil uji menggunakan perhitungan $\mathrm{N}$-Gain menunjukan peningkatan setelah pembelajaran dengan menggunakan model pembelajaran inkuiri terbimbing berbantukan video animasi, yaitu pada keterampilan berpikir kritis kelas VIII A sebesar 0,53 sehingga dapat disimpulkan bahwa skor rata-rata keterampilan berpikir kritis peserta didik yang diajarkan dengan model pembelajaran inkuiri terbimbing berbantukan media animasi berada pada kategori sedang.

Hasil analisis deskriptif untuk tiap sub indikator berdasarkan Tabel 5 dapat dijelaskan sebagai berikut: (1) Mengidentifikasi dan merumuskan kriteria untuk mempertimbangkan kemungkinan jawaban kategori sangat baik karena peserta didik terbiasa pada setiap pembelajaran guru banyak menyajikan permasalahan yang menuntut peserta didik untuk merumuskan masalah mengidentifikasi kemungkinan jawaban atas permasalahan tersebut. Misalnya peserta didik di sajikan sebuah permasalah mengenai apakah sama letak dan bentuk pembuluh akar monokotil daan dikotil; (2) Mengidentifikasi dan merumuskan pertanyaan kategori baik karena pada setiap pembelajaran guru banyak 
menyajikan permasalahan yang menuntut peserta didik untuk mengidentifikais masalaha permasalahan kemudian merumuskan masalah. Pada sub indikator ini peserta didik mengalami beberapa kesulitan saat mengidentifikasi dan merumuskan sebuah pertanyaan sehingga membuat nilai pada sub indikator ini menjadi nilai terendah; (3) Mengidentifikasi Kesimpulan kategori baik karena pada setiap pembelajaran peserta didik terbiasa mengidentifikasi dari suatu masalah maupun soal-soal yang telah disajikan; (4) Memberikan penjelasan kategori baik karena peserta didik pada saat pembelajaran dituntut untuk memberikan penjelasan dari hasil yang telah didapatkan; (5) Menyebutkan contoh kategori baik karena peserta didik karena pada saat pembelajaran peserta didik mampu memberikan contoh dari hasil mengidentifikasi suatu permasalahan; (6) Mempertimbangkan penggunaan Prosedur dengan tepat kategori sangat baik karena peserta didik telah terbiasa pada setiap pembelajaran guru menuntut peserta didik untuk menetukan langkahlangkah yang tepat untuk menemukan jawaban. Pada sub indikator ini siswa lebih memahami diliat dari hasil nilai per sub indikatornya mendapat nilai tertinggi diantara sub indikator lainnya; (7) Menarik Kesimpulan dari hasil penyelidikan kategori baik karena peserta didik telah terbiasa pada setiap pembelajaran model inkuiri terbimbing berbantukan media animasi. Misalnya guru memberikan tanyangan tentang jaringan pada tumbuhan kemudian peserta didik dapat menjelaskan pembagian jaringan tumbuhan secara rinci dan tepat.
Model inkuiri terbimbing berpengaruh signifikan terhadap kemampuan berpikir kritis. Hal ini diperkuat oleh Kindsvatter, William dan Ishler (Suprihatiningrum, 2013) menyatakan bahwa inkuiri terbimbing adalah sebuah pendekatan, yang mana guru melibatkan keterampilan berpikir kritis peserta didik untuk menganalisis dan memecahkan persoalan secara sistematik melalui identifikasi persoalan, membuat hipotesis, untuk membuktikan hipotesis yang telah dibuat peserta didik melakukan pengumpulkan data, menganalisis, mengolah data dan menarik kesimpulan yang telah di telusuri dengan menuliskan hasil pengamatan.

Hal tersebut diperkuat dengan adanya asumsi-asumsi yang mendasari strategi pembelajaran inkuiri terbimbing, seperti yang dikemukakan oleh (Hamalik, 2013) yaitu kemampuan berpikir kritis berhubungan dengan pengumpulan data dan hipotesis yang terdapat dalam sintaks pembelajaran inkuiri terbimbing berbantukan peserta didik mendapat keuntungan dengan strategi pembelajaran inkuiri terbimbing dapat berkomunikasi, bertanggung jawab dan bersama-sama mencari pengetahuan dengan kegiatan pembelajaran dengan semangat menemukan jawaban menambah motivasi peserta didik. Hal senada disampaikan oleh pendapat (Roestiyah, 2001) yang menyatakan bahwa inkuiri terbimbing merupakan salah satu strategi pembelajaran yang menekankan pengalaman langsung kepada peserta didik untuk mencari konsep pengetahuannya.

Penelitian ini diperkuat oleh (Ferdian, 2016) menyatakan bahwa pembelajaran 
menggunakan multimedia animasi dapat memberikan peningkatan kemampuan berpikir kritis. Temuan ini sejalan dengan penelitian Mulyani (2014) keterampilan berpikir kritis peserta didik yang dibelajarkan dengan menggunakan pembelajaran berbasis masalah bermedia animasi secara signifikan lebih tinggi dibandingkan kemampuan pemecahan masalah biologi peserta didik yang dibelajarkan tanpa media animasi.

Kondisi yang dijelaskan dalam pembahasan belum dapat menjabarkan secara keseluruhan terkait keterampilan berpikir kritis siswa berbantukan media animasi pada materi ajar Struktur dan Fungsi Jaringan Tumbuhan karena keterbatasan jumlah sampel dan populasi. Animasi yang digunakan pun dapat digunakan dari berbagai media pengolahan animasi yang terjangkau dan dalam kapasitas kemampuan peneliti.

\section{SIMPULAN}

Berdasarkan hasil penelitian dan pembahasan dapat disimpulkan keterlaksanaan model pembelajaran inkuiri terbimbing berbantukan media animasi pada materi struktur dan fungsi jaringan tumbuhan kelas VIII A MTS Islamiyah Palangka Raya telah terlaksana dengan baik dengan persentase sebesar $84,09 \%$.

Penyusaian media pembelajaran direkomendasi dalam penelitian ini bagi peneliti selanjutnya karena pentingnya kesesuaian materi yang diajarkan dengan ketercapaiaan yang disusun sebagai indikator dalam pembelajaran.

\section{DAFTAR PUSTAKA}

Hamalik O. 2013. Proses Belajar Mengajar. Jakarta: Bumi Aksara

Lestari I. 2019. Berpikir Kritis dalam Konteks Pembelajaran. Jakarta:Erzamata Karya Abadi.

Ridho M. 2017. Pengaruh Media Animasi dan Penggunaan Awal Siswa Terhadap Siswa Pada Materi Sistem Pencernaan Manusia SMA Swasta Hang Tuah Belawan. Jurnal Tabularasa PPS Unimed, 14(2): 1-10.

Roestiyah NK. 2001. Strategi Belajar mengajar. Jakarta: Rineka Cipta

Suprihatiningrum J. 2013. Strategi

Pembelajaran Teori dan Aplikasinya. Yogyakarta: Ar-Ruzz Media.

Suhandi .2014. 68 Model Pembelajaran Inovatif dalam Kurikulum 2013. Yogyakarta: Ar-Ruzz Media.

Wahyuni S. 2018. Penerapan Model Inkuiri Terbimbing dalam Meningkatkan Kemampuan Berpikir Kritis pada Pembelajaran Fisika. Education and Development, 3(1):1-7

Warda A, Sudibyo E. 2018. Keterampilan Berpikir Kritis Siswa dalam Implementasi Model Discovery Learning pada Sub Materi Pemanasan Global. Journal Pensa(02), 238-242.

Aji RH. 2020. Dampak Covid-19 Pada Pendidikan di Indonesia:Sekolah,Keterampilan dan Proses Pembelajaran. Jakarta: UIN Syarif Hidayatullah. 
Al-Darimi. (n.d.). Beirut: Dar Al-Fikr. In A. M. Al-Darimi, Juz 1.

Arikunto. 2006. Prosedur Penelitian Suatu Pendekatan Praktik. Jakarta: Rineka Cipta .

Selviana D, Susanti R, Iswari RS. 2016). Pengembangan LKS Berbasis Inkuiri Terbimbing Pada Materi Struktur dan Fungsi Jaringan Tumbuhan di SMP. Unnes Journal of Biology Education, 5(2): 123-128.

Lestari, I. 2019. Berpikir Kritis dalam Konteks Pembelajaran . Jakarta: Erzamata Karya Abadi.

Maryam. 2019. Pengaruh Model Pembelajaran Inqury Terhadap Berpikir Kritis Siswa Kelas XI MIA MAN 2 MATARAM.

Ridho, M. 2017. Pengaruh Media Animasi dan Penggunaan Awal Siswa Terhadap Siswa Pada Materi Sistem Pencernaan Manusia SMA Swasta Hang Tuah Belawan. Jurnal Tabularasa PPS Unimed, 14(2).

Sunardjo RN, Yudhianto SA, Rahman T. 2016. Analisis Implementasi Keterampilan Berpikir Dasar dan Kompleks dalam Buku IPA Pegangan Siswa SMP Kurikulum 2013 dan Implementasinya dalam Pembelajaran. Proceeding Biology Education Confrence, 13(1): 133-144.
Siswandi. 2011. Metode Satistika. Bandung: Tarsito.

Suryobroto. 2002. Proses Belajar Mengajar di Sekolah. Jakarta: Rineka Cipta.

Susilowati. 2017. Analisis Keterampilan Berpikir Kritis Siswa Madrasah Aliyah Negeri Magetan. . Prosiding Seminar nasional Pendidikan SAINS Universitas Sebelas Maret.

Trianto. 2012. Mendesain Model Pembelajaran Inovatif-Progresif. Jakarta: Kencana Prenada Media Group. Wulandari DA. 2019. Penagaruh Model Discovery Learning Terhadapa Kemampuan berpikir kritis siswa pada konsep sistem ekskresi dI MAN 13 Jakarta.

Yeritia, S; Rahayu, S; Wahyudi. 2017. Pengaruh implementasi model pembelajaran inkuiri terbimbing terhadap penguasaan konsep daan kemampuan berpikir kritis fisika peserta diidk kelas X SMAN 1 Kuripan Tahun ajaran 2017/2018. Jurnal pendidikan fisika dan Teknologi.

Zubaidah. 2017. Keterampilan Abad Ke 21, Keterampilan yang diajarkan melalui pembelajaran. Universitas Negeri Malang. 